\title{
A contextually adapted model of school engagement in Kazakhstan
}

\author{
Liz Winter $^{1}$ (1) $\cdot$ Daniel Hernández-Torrano ${ }^{2} \cdot$ Ros McLellan $^{1} \cdot$ Ainur Almukhambetova $^{2} \cdot$ Eva Brown-Hajdukova $^{3}$
}

Published online: 1 May 2020

(C) The Author(s) 2020

\begin{abstract}
This study introduces a culturally adapted 17-item scale of school engagement. It offers an important contribution to the international literature by seeking to measure the school engagement of young people in a society undergoing transition from a collectivist to individualist mind-set alongside an education system focused on improving performance in international benchmarks such as those from the Organisation for Economic Co-operation and Development (OECD Programme for International Student Assessment, PISA) and the International Association for the Evaluation of Educational Achievement (IEA Trends In International Mathematics And Science Study, TIMSS). To date, little has been written on how intra-individual and interindividual factors contribute to young people's engagement in education as societal and systemic educational reform occurs. The school engagement scale is validated by testing the empirical fit of a second-order multidimensional factor model of school engagement taken from the Western literature to large-scale data in Kazakhstan. Culturally relevant features are added such as the strong influence of 'important others'. The model tested was formed from 1) an individual's cognitions and behaviours associated with school and 2) the social influences of parents, peers, and teachers. 1767 secondary education students in Kazakhstan participated in the study. Confirmatory analyses supported the hypothesized additional contributory factors to school engagement. Use of the overall model indicated differences in means across gender, grade, school-type, and geographic location to show: (1) higher cognitive engagement for young women; (2) rural students with higher levels of behavioural engagement; and (3) substantial differences in social support by grade and rurality.
\end{abstract}

Keywords School engagement · Measurement scale $\cdot$ Contributory factors $\cdot$ Post-soviet $\cdot$ Kazakhstan $\cdot$ Attitudes to school · Societal transformation

\section{Introduction}

This paper sets out to provide original insight on the topic of modelling and measuring school students' engagement in Kazakhstan, as an example of a post-Soviet society and an education system undergoing rapid transition towards a more individualised Western model. A subsequent aim of the paper is to examine how a validated and culturally adapted measure of school engagement varies across a set of key demographic and contextual factors thereby providing novel empirical

Liz Winter

eaw53@cam.ac.uk

1 Faculty of Education, University of Cambridge, 184 Hills Road, Cambridge CB2 8PQ, UK

2 Graduate School of Education, Nazarbayev University, 53 Kabanbay Batyr Avenue, Nur-Sultan City, Kazakhstan

3 Clinical Outcomes Assessment, Parexel London, Northwick Park Hospital, Watford Road, Harrow, Middlesex HA1 3UJ, UK evidence on factors associated with greater levels of school engagement in Kazakhstan.

As with many countries undergoing change, Kazakhstan's stated aspirations for its educational system revolve around improving test scores in international assessments such as PIRLS, PISA and TIMSS (OECD 2018). To achieve this, there has been considerable investment in the education system and substantial institutional change including an entire overhaul of higher education (Hartley et al. 2016) and the school system (Bokayev 2016; Bridges 2014). Politically, tangible returns on this investment in education are important. This is both internationally and at home to present a forward-looking trajectory of nation-building and a growing world presence (Alexander 2012). Kazakhstan is now a generation away from its communist past, following independence in 1991. Arguably, if the educational aspirations of policymakers are to be realised, young people should by now conform to a Western model of individualised attainment; with a suitable school climate and social support to facilitate this. Commensurately, young people's attitudes in Kazakhstan towards school should bear relation to a Western model of school engagement. 
There is little research on how school engagement changes during such transition periods, and it is not clear that well validated Western measures of school engagement can simply be applied to such a different context. Using an adapted measure of school engagement, this paper presents exploratory research and the first empirical evidence on this issue from a post-Soviet soceity intended to undergo transformation. Effectively, this paper hypothesises that the model of school engagement seen in Kazakhstan should contain influences from within the individual, as seen in the Western literature and contexts, but also, again as seen elsewhere, depend on support from important others. It is the balance of these contributions that are unknown alongside any differences between social groups in the country that may affect matters. This claim is predicated on young people in Kazakhstan having only second-hand experience of communism such that any self-definition through the collective has diminished to the point of recognising individual self-efficacy and actions that determine attitudes towards school. The research seeks to identify universal and context specific factors which promote or detract from school engagement and hence can guide policy in Kazakhstan's aim to develop its youth's educational outcomes. The paper will end with recommendations for future research and applications of a culturally valid model that can profit deeper and more specific inquiry.

Apart from this study's direct relevance for Kazakhstan, in general there is a paucity of research on the topic of how fundamental changes in society's attitudes towards personal responsibility and autonomy of study affect young people's attitudes towards school. This work seeks to address this. Charting how attitudes are constructed within an empirical paradigm, combined with a culturally sympathetic approach, will indicate ways forward in capturing the perspective of pupils during fundamental change to the education system as concurrent changes from a collectivist to a more individualised society occur. We therefore focus on the most peripheral and final link in a chain of rapid and dramatic change, that is the end-point of pupil attitudes. Although the focus is on Kazakhstan, more general comparisons with societies in transition and aspiring to Western models of education, such as other former Soviet Union (fSU) nations and China, are clearly relevant (e.g. Bear et al. 2018).

\section{The Purposes of Schools in Transition Societies}

According to Adler (1982), the purpose of school for students is threefold: to learn, enjoy and apply appropriate patterns of social interaction; to instrumentally leave with sufficient personal character and resources to provide as much fiscal security as possible for whatever the future may hold; and, to permit the first two purposes, to set oneself up for a lifetime of learning through the creation of a receptive mind-set. In effect, Adler's (Western) purposes of school are: learning how to behave; learning enough to become employable; and, of paramount importance, learning how to learn. To achieve success across these three aspects, young people need to engage with school and make it personally relevant to recognise and realise these goals as befits their ambitions (Bronfenbrenner 1979; Osterman 2000).

Regarding the socialisation purpose of school, endorsing the social norms of behaviours for young Kazakhstanis has required a major overhaul since independence. Personal expectations and responsibilities have been required to shift from a collectivist to a capitalist set of values (Biyekenova et al. 2016). Similarly, Adler's second purpose of school, an instrumental aim to gain employment, has also had to change as the country moves from full, lifetime-employment to a competitive and uncertain job market. Relaxation of the tight control on uniformity across the employment and education systems from a central Soviet bureaucracy has meant that opportunities in Kazakhstan have predictably become more uneven (Rigi 2003). Outcomes for students now vary at group level. Rural or urban location, the effects of internal and external migration, differences in school and local facilities, variable teacher quality, and available jobs all impact on young people's opportunities through education (OECD/World Bank 2015). In urban areas, through patchy affluence and parental choice, private schools and paid tutoring have emerged as common phenomena. In parallel, school dropout and a bifurcation of attitudes towards school has led to significant numbers of disaffected and unemployed youth (Rigi 2003). An additional factor has been the introduction of a high-stakes national test in 2004, which has considerably changed attitudes towards what qualities are sought for entry to higher education (Winter et al. 2014a). A need for incorruptible external evaluations to select students rather than rely on schools' recommendations and universities' own procedures has certainly impacted on how students engage with leaning in the later years of school (see OECD 2018; Oka 2018; World Bank 2002).

Adler's paramount purpose of school, to teach young people the skills to become receptive, open, lifelong learners of the twenty-first Century, has still to be fully realised in Kazakhstan (OECD 2018). This paper seeks to provide evidence on one important aspect of the wider educational transformation being undertaken in Kazakhstan, namely the extent to which students now engage with school.

\section{School Engagement: Its Visibility and Importance}

Often, the first sign of school (dis)engagement stems from observable behaviours with the most extreme form of disengagement being school dropout or intermittent attendance. Sadly, dropout or non-attendance have long-standing and 
potentially lifetime negative implications (Ceci and Williams 1997). Even if a pupil attends school, they may display other observable behaviours reflecting disengagement; such as disruptive acts, not listening to instructions or non-completion of tasks. This can similarly affect outcomes. Hence behavioural engagement is strongly correlated with academic performance across all students (Green et al. 2012). There is also some evidence that attitudes towards education impact on young people's mental health (Suldo et al. 2014), which is an issue of great importance in Kazakhstan and other former Soviet Union countries given their relatively high young male suicide rates (WHO 2018). Thus, measuring and understanding the factors that drive school engagement in a culturally sensitive manner is important, not just for predicting students at risk of drop out but also potentially to devise policies and early warning systems to improve educational and mental health outcomes (White and Murray 2015).

\section{School Engagement: Its Factors}

Fredricks et al. (2004) suggest three dimensions to student engagement: the psychological tenets of cognition, affect and behaviour. Firstly, behavioural engagement is manifest by students who follow the social norms: attend school regularly, do not exhibit disruptive behaviours and who work constructively to complete school work. Next, affective engagement is indicated by students who feel they belong, enjoy coming to school, and who do not report negative emotions. Finally, cognitive engagement refers to students who are stimulated to extend their learning beyond the required minimum. For example, cognitively engaged learners seek opportunities to personally invest in the learning process through asking questions, unrequested private study and actively incorperating new material in extant knowledge structures. These three components are usefully summarised by Appleton et al. $(2006,2008)$ who name behavioural, affective and cognitive components of engagement as 'indicators' and contextual factors that drive these variables as 'facilitators'.

In terms of measurement and construct validity, James Appleton's work has been developed by Andrew Martin (Liem and Martin 2012; Martin 2007). The latter identifies first- and higher-order factors surrounding cognitions and behaviours that drive motivation and engagement in school. Martin (2007) identifies four higher-order factors as positive and negative contributors to school engagement through adaptive and maladaptive cognitions and behaviours. He also suggests 11 more fundamental aspects that load on these: selfefficacy; valuing; mastery orientation; anxiety; failure avoidance; uncertain control; task planning; task management; persistence; self-handicapping and disengagement. Martin (2007) initially validated his MES-HS scale (Motivation and Engagement Scale - High School) in a large-scale study in
Australia but it has since been translated and applied in China (Martin and Hau 2010), where its construct validity was confirmed. Although this is not fulsome support for its cross-cultural validity, it does provide some confidence to reapply the scale in a further non-Western context to examine these constructs of this school engagement model. Whilst Martin (ibid.) pays less attention to affective engagement and the influence of important others, he espouses strongly that the twin aspects of self-determined behaviour and selfcognition are significant factors to school engagement, and which together drive the variances found in measures of such.

Considering school engagement merely as a consequence of cognitions and behaviours omits the role of emotional factors recognised by Fredricks et al. (2004) and so, as argued by some, cannot fully represent the holistic experience of students. However, as a counter to this, mood-states within a learning environment are often of a transitory nature and do not necessarily translate to more long-standing attitudes with a fine balance between mastery of easy tasks versus coping techniques for more challenging demands (Boekaerts 1993). Indeed, teasing school engagement apart from a broader and more enduring sense of wellbeing in school is a difficult task; with some models of wellbeing such as the PERMA model (Seligman 2011) including engagement as a contributory factor - albeit one that is, importantly, conceptually distinct and constructed independently of positive emotions.

Capturing an emotion without also asking what an individual does with that emotion through self-regulation has limitations. For example, a well-prepared individual knows they are anxious approaching an examination but uses this positively to harness adrenalin towards sharper attention and a better focus on recall, drawing on social facilitation to perform above their usual level. By contrast, an ill-prepared student who exhibits social inhibition will find that the same scenario reduces their performance below their personal average (see, originally, Zajonc 1965 and, more recently in a non-Western context, Lam et al. 2004). Taking this further, self-perceived emotions can be moderated through use of an individual's emotional intelligence to significantly adapt thoughts and behaviours regarding school and hence to improve attainment and engagement (Petrides et al. 2004). Hence, any measure of affect also requires simultaneous tracking of an individual's emotional intelligence. By contrast, measuring cognitions and behaviours affords more clear-cut, direct and mutable ways of helping individuals achieve Adler's triple aims of becoming an effective learner, socially well-adjusted, and academically successful.

\section{School Engagement: Appraising Sources of Influence Rather than Motivation(S)}

International literature on school engagement (see Martin 2016) supports the view that the influences on an individual's engagement in school stem from two sources: personal influences and 
desires from within; and, from all others who stand without. How these two factors are represented and interact in the political and culturally dynamic setting of an evolving nation such as Kazakhstan is therefore of significant interest as the purposes of school change. The argument for dual influences from within and outside the individual that form attitudes towards school has clear parallels to motivation at school stemming from selfdetermination theory (SDT) as it relates to the psychological needs of students being met through an adequate sense of competence and autonomy alongside satisfactory relationships with others (Ryan and Deci 2000).

The role of motivation will be revisited elsewhere in the article and we acknowledge that motivation is closely related to engagement but for the purposes of this article, we adhere to the distinction between engagement and motivation as made by Skinner and Belmont (1993). As with Skinner and Belmont (ibid.), we seek to adopt a more socially inclusive model where the reciprocal effects of student behaviour on others and vice versa are modelled. For example, a teacher observing a passive, seemingly disengaged student affects their behaviour by focusing on a student with more obvious engagement to reward their attempts to teach and so a selffulfilling cycle begins as students form attitudes of how they themselves are seen by others. Similarly, children labelled as 'academic' or not by families, alongside general expectations and support by peers and families, can be better modelled through an engagement model rather than an individually orientated model of motivation.

Apart from limiting school engagement to be based primarily on cognitions and behaviours, there is clearly much debate as to how school engagement and motivation are defined conceptually, overlap and interact (Martin et al. 2017). It has been argued by others (e.g. Wang and Eccles 2013) that engagement cannot occur until the psychological needs of individuals are met and hence the prerequisites to create a motivated learner are in place (Ryan and Deci 2000). This means engagement in relation to school environment can act as a proxy for academic motivation in relation to school context without motivation itself being drawn out as a separate measure, since motivation is merely one factor in many that forms a more general attitude towards school (Wang and Eccles 2012). To conclude from the above, it is clear how students think, feel, behave and are motivated regarding school are interwoven. However, for the mechanics of looking at internal and external influences on attitudes towards school, treating end-emotions and motivation as a consequence or third order effects of the thoughts and behaviours of the individual and others may serve reasonably well.

\section{School Engagement: Important Others}

Despite a general trend during adolescence for disengagement to occur (McDermott et al. 2001; Simons-Morton and Chen
2009), and the lessening importance of the family as a source of influence during this period (Cummings et al. 2000), much research indicates that familial support and attitudes towards formal education are critical in terms of students' school engagement (Christenson and Thurlow 2004; Ou 2005; Rodríguez-Fernández et al. 2012; Sinclair et al. 2003). Family stability, cohesion and togetherness have also been linked to higher levels of students' school engagement (Annunziata et al. 2006; Bowen et al. 2008). Several studies have pointed out that parental monitoring and authoritative parenting practices positively influence school engagement in early adolescents (Bartle-Haring et al. 2012; SimonsMorton and Chen 2009) and at-risk students (Annunziata et al. 2006). Similarly, high but realistic parental expectations have further been found to promote school engagement (Woolley and Bowen 2007).

Concerning the school environment, there is substantive evidence that teachers exert a significant and direct effect on student school engagement (Furrer and Skinner 2003; Perry et al. 2010). Indeed, Fernández-Zabala et al. (2016) found teacher support to be the variable with the greatest explanatory capacity to predict all types of school engagement, compared to other sources of social support such as family and peers. As additional evidence, a meta-analysis conducted by Roorda et al. (2011) showed medium to large associations between teacher-student relationships on school engagement, with stronger effects on secondary education. Other studies suggest that middle and high schools who perceive that their teachers value them, care about them, respect them and are fair to them are more likely to be engaged and attached to their schools (Hallinan 2008; Kelly and Zhang 2016). However, a few studies have challenged this connection and found no effect of teacher support on school engagement (e.g. Bowen et al. 2008; Daly et al. 2009).

The study of the relationship between peer support and school engagement has yielded contradictory results. On the one hand, a considerable number of studies suggests that peers have a positive influence on school engagement. For example, Furrer and Skinner (2003) found that relatedness to peers acts as a significant predictor of self-reported behavioural and affective school engagement in middle and high school. Similarly, Perdue et al. (2009) found that the quality of close friendships and social support from peers positively predicts middle school engagement. On the other hand, several studies have found a negative relationship between peer support and school engagement (e.g. Fernández-Zabala et al. 2016) and detrimental effects of peers on school classroom participation and school attainment. For example, students who experience early and chronic peer rejection, exclusion, and abuse report lower levels of classroom participation and increased desire to avoid school (Buhs and Ladd 2001; Buhs et al. 2006). Moreover, some studies have failed to find a relationship between peer support and school engagement at all (e.g., Bowen 
et al. 2008; Daly et al. 2009; Lam et al. 2012; RodríguezFernández et al. 2012; Virtanen et al. 2014).

Therefore, it appears that there are three direct sources of influence on students' school engagement which come in many forms and with conflicting levels of evidence, but which centre on family members, teachers and peers. Secondary influences come from educational policies and senior leadership in a school that may shape a school's ethos and value systems, the media, cultural norms and other wider social influences but these are not generally explored in the literature and so will not be included here.

\section{The Kazakhstan Context}

There are 1.6 million children in secondary education and 1.2 million in tertiary education in Kazakhstan. The majority finish school aged 17 (Grade 11) but remain in education through a mix of TVET colleges and universities until they are aged 21 (UNESCO 2018). The staffing ratio of teachers to students is generous in Kazakhstan with official figures suggesting that the average ratio in secondary education, including many teachers acting as specialist methodologists or in senior management roles, is 6.96 pupils per teacher (UNESCO 2018). Current legislation stipulates the ratios of teachers to students with little flexibility, which many observers comment is something that needs systemic rationalisation to employ fewer but better paid and higher quality teachers in the classroom (OECD/World Bank 2015).

Kazakhstan, in common with many other post-Soviet countries, is in the process of passing over more direct control for children's development from the state to the family (Mead and Silova 2013). Hence, parental support may be an increasingly important factor in school engagement in Kazakhstan (Kulakhmetova 2017). Evidence supporting this stems from research that suggests children from larger and/or low socioeconomic families and those who experience poor relationships with teachers appear to be significantly more at risk for school dropout in Kazakhstan (ESP 2007; Antonowicz 2013). The dynamic between private and communal responsibilities are symbolised by the culturally engrained frequent and public competitions (Olympiads) that operate at all levels of accomplishment to act as public recognition of academic achievement and excellence (Astana Times 2019). Entrants are chosen by schools and coached on a one-to-one basis with funds raised communally to support travel to more distant and higher-level Olympiads. Thus, despite the shift to a more individualised model of educational, the critical and overlapping role that teachers, parents and their communities have as a kollective remains to this day (Hernández-Torrano and Tursunbayeva 2016).

As noted previously, there is an uneven pattern of educational provision in Kazakhstan with acknowledged differences in performance in the national test scores between urban and rural locations (Musina 2015). Indeed, to compensate for this, there are reserved quotas for some higher education specialties for students from rural areas (MoJRK 2012). An additional facet to variation in the type of education received by students in Kazakhstan is the setting up of an autonomous organisation to govern what are called Nazarbayev Intellectual Schools (NIS). This network of 20 selective schools is evenly distributed around Kazakhstan to deliver 12-year schooling as opposed to the mainstream 11-year norm. NIS are positioned to be a piloted model for reform of the whole educational system and afford a more international curriculum, teaching methods and well-above average facilities and resources (Bridges 2014). In general, schools in Kazakhstan are clustered to be one of five types: NIS; a specialist Lyceum or Gymnasium; an urban mainstream school; a rural mainstream school; or a small village school that may or may not involve multi-grade teaching in some classes (IAC 2019). The latter two of these types are deemed rural schools and the remainder, urban.

\section{A Model of School Engagement for Kazakhstan}

Martin (2016) models school engagement as a combination of an individual's cognitions and behaviours. This sensibly allows school engagement to be framed as an attitude towards school and schoolwork to then apply the principles of attitude formation (Ajzen and Fishbein 1980). Whether the individual applies the peripheral route to attitude formation which is based on affect and pleasing conscious or unconscious associations with school or whether the individual takes a central or direct informational approach through conscious reasoning of the benefits of qualifications or other trade-offs is less relevant than the endpoint: a positive or negative attitude and likely compliance or non-compliance to the demands of school. However, what is clear is that the latter of these routes, conscious informational thoughts, is generally more open to change than the former. This is primarily because the central route to attitude formation is more available to cognitive transformation through the persuasive arguments of others than the peripheral, emotional route that works on implicit rather than explicit attitudes. Hence, it is important to model school engagement with students' cognitions as explicit variables and to examine these as well as the larger picture across groups to identify problems and then to measure the performance of any remedial interventions that change students' attitudes for the better.

Consistent with the previous discussion, looking at school engagement as an attitude allows it to be represented as a continuum with each student holding a position somewhere between the poles of rejection and non-attendance through to 
school being a very central part of life. Indeed, attitudes run through the three stages of conformity, then compliance and finally conversion which, looking through the lens of Adler's (1982) purposes of education would equate, respectively, to social preparation, academic preparation and becoming learning prepared. Lower levels of school engagement would represent a demonstration of conformity by a student simply agreeing to abide by social obligations and norms through attendance. The next attitudinal level of compliance would extend this behaviour by a student agreeing with the reasons behind attending school. However, compliance may be based on an instrumental approach that supports strategic behavioural engagement to produce success as a means to an end. For example, working hard enough to pass a test but not striving to excel in it. Higher levels of engagement and the most positive attitudes towards school culminate with conversion that represents an individual being convinced of the personal relevance of school and academic success therein to develop the foundational skills important in a lifelong love of learning. In line with Martin's definitions of higher school engagement (Martin 2007), the most positive attitudes towards school derive from the higher-order factors of supporting (vs. distracting) cognitions and adaptive (vs. maladaptive) behaviours at the intra-individual level; effectively akin to intrinsic motivation and Adler's openness to learn through a receptive mindset.

\section{Research Aims and Research Questions}

Locating and validating a model of school engagement for Kazakhstan and other post-communist nations is overdue. Bringing measures of school engagement forwards as a contribution to the general discourse on improvements in education in Kazakhstan, the wider region of Central Asia and other former Soviet Union nations is timely. Generation by generation, many of these countries continue to accommodate societal transformation. Policymakers within such countries need to be advised with evidence so they may consider students' attitudes towards education especially if it is a tenet of nationbuilding and a demonstration of visible modernity on the global stage. Any country in societal transformation that oft includes modernisation of its educational system needs to map change in students' behavioural responses and thoughts or else it will be unsure of direction and progress, Thus, the primary research aim is to to construct a theory-led means of measurement, road-test it by examining its general performance and then asks if any indicated differences in social groups exist as preparation for fuller inquiry.

There is no such instrument available and, as the literature demonstrates, first examination of age and gender differences seen elsewhere would inform on their naturein Kazakhstan to explore any universal versus context dependent factors (see
Fredricks et al. (2004) for a discussion of age effects and Fernández-Zabala et al. (2016) for a discussion of gender differences). Effectively, how does school engagement in Kazakhstan vary - across grades and is there a gender difference as found in the West? Taking the latter of these questions first, as the Western literature would suggest, are young women in Kazakhstan more behaviourally engaged than young men whilst exhibiting little difference in cognitive engagement?

Making comparisons with how school engagement varies with grades from one education system to another is problematic as it requires controlling for differences between cohorts of the influence of compulsory versus post-compulsory stages in students' careers. Meaningful international contrast is difficult since the structure of educational systems are highly influential in shaping students' attitudes towards school. Separating out more general features of adolescent development such as increasing social maturity and the value of family versus peer relationships is a further challenge. As Fredricks et al. (2004) suggest, detail is of importance here and the most useful research findings should be aimed at a local rather than international audience although general observations would still be good background in such an article as this to inform on national trends. It is also important to note that conformity in the Soviet era was mandatory and continues in Kazakhstan to this day with fines for parents and published league tables for schools if students fail to attend. As the OECD concludes: 'Attendance is almost universal' (OECD/The World Bank 2015: 29). Students in Kazakhstan may leave school after Grade 9 so looking at differences between those obliged to attend and those thereafter should inform on levels of engagement stemming from forced versus optional attendance. Insight to levels of compliance versus conversion should they vary with grade may also become apparent.

Kazakhstan has a difficult topography with inequality in the quality of education provided. This is already established as a concern for rural versus urban settings so exploring application of a more broadly validated model could, again, provide first steps in looking at the level and type of differences seen in school engagement as one factor among many. The final area to seek difference in this article is in the type of school as an initial attempt to represent the roles of selective entry versus open entry for schools in Kazakhstan. As discussed above, Kazakhstan values competition in the recognition of educational attainment through Olympiads and outstanding performances in national tests. So, how students differ between schools that demonstrate the prowess of their students publicly versus mainstream schools that rely on a catchment area is of interest. This would potentially provide insight as to the role of academic expectations and school ethos as it influences students' school engagement. 


\section{Method}

\section{Participants}

The sample included 1767 secondary education students (863 female) aged from 12 to 18 years $(M=15.23, S D=1.07)$ from 22 schools in six different locations across Kazakhstan; 4 schools were located in the North-centre region of the country, 4 in the North-West, 4 in the South-centre, 4 in the SouthWest, and 6 in the West. Schools were purposefully selected to represent a wide array of cultural norms, ethnicities, language backgrounds, and income levels. From the total sample, 1227 were ninth- and 10th-graders (i.e. in school years that signalled the final year of compulsory schooling and the first year thereafter) and 540 were 11th- and 12th-graders (in their final year at school). Among them, $10.4 \%$ were studying within the network of selective urban schools, $16.5 \%$ in specialized urban schools (i.e., lyceum and gymnasiums), 33.1\% in mainstream urban schools, $34.4 \%$ in large village schools, and $5.6 \%$ in small village schools. All in all, $60 \%$ of the students were living in urban settings, and $40 \%$ in rural settings (see Table 1).

\section{Instrument}

Based on the principle described previously of attributing school engagement to internal and external sources, i.e. individual characteristics (intra-personal) and the social (interpersonal) influence of others (parents, peers and teachers), a questionnaire was developed to measure school engagement. The questionnaire comprised three sections.

Table 1 Demographic Characteristics of the Sample

\begin{tabular}{lll}
\hline & $\mathrm{n}$ & $\%$ \\
\hline Gender & & \\
Female & 863 & 54.1 \\
Male & 731 & 45.9 \\
Grade & & \\
Ninth & 693 & 39.2 \\
Tenth & 534 & 30.2 \\
Eleventh & 510 & 28.9 \\
Twelfth & 30 & 1.7 \\
School cluster & & \\
Urban selective & 184 & 10.4 \\
Urban specialized & 292 & 16.5 \\
Urban mainstream & 585 & 33.1 \\
Village large & 607 & 34.4 \\
Village small & 99 & 5.6 \\
Geographic location & & \\
Urban & 1061 & 60 \\
Rural & 706 & 40 \\
\hline
\end{tabular}

In the first section, demographic data were collected regarding the student's gender, grade, type and location of school attended. In the second section, 10 items focussed on school engagement at an intra-personal level through students assessing how typical specific thoughts and behaviours were of themselves. The 10 items were taken as a sub-set of the nominated 'typical' items from Martin's larger 44-item Motivation and Engagement Scale - High School survey (Martin 2007). The intra-personal items loaded on three aspects to school engagement: adaptive cognitions (positive thoughts about school); adaptive behaviours (positive behaviours towards school work); and maladaptive cognition and behaviours (negative thoughts and behaviours concerning school and/or school work). Martin's suggested negative affect item regarding examination anxiety was removed based on the decision that not only did it fail to relate directly to cognitions and behaviours, but also as data collection took place in October, this was too remote for students' considerations regarding the examinations due in May. The third section of the questionnaire examined inter-personal factors by means of eight culturally appropriate items that recorded students' perceptions of positive social influence from others in relation to school. Of these, three items measured parent support, three items measured teacher support, and two items measured peer support. The items measuring parent and teacher support were adapted from the Adolescent Health Attitude and Behavior Survey (AHABS) (Reininger et al. 2003). The items measuring peer support represent a selection of typical items in the Multidimensional Students' Life Satisfaction Scale (MSLSS) (Huebner 2001). For each item in the second and third sections of the instrument, students rate themselves on a scale of 1 ('strongly disagree') to 5 ('strongly agree').

The questionnaire was designed in English and then translated into Russian and Kazakh languages following the guidelines for translating and adapting tests promulgated by the International Test Commission (2017). Table 2 shows the items of the questionnaire, as well as the hypothesized theory loadings based on Martin's (2007) multidimensional model of student engagement.

\section{Procedures}

Firstly, permission to approach the selected schools was requested from the corresponding regional education departments. The background and purpose of the research was explained along with its anonymity. Next, the school principals were contacted for assurance of their interest in participation and, if agreeable, to consult with their staff in order to compile as non-disruptive a schedule as possible for a visit. At each school, with principals' and teachers' in-loco parentis permissions in place, pairs of the research team spoke to students in the language of instruction, one class at a time during normal lessons. Again, the background and purpose of the research 
Table 2 Survey items and hypothesised theoretical loadings

\begin{tabular}{|c|c|c|c|}
\hline \multirow[t]{2}{*}{ \# } & \multirow[t]{2}{*}{ Item } & \multicolumn{2}{|c|}{ Martin (2007) constructs } \\
\hline & & Higher-order & First-order \\
\hline Q1 & If I try hard, I believe I can do my schoolwork well. & Adaptive & Self-efficacy \\
\hline Q2 & Learning at school is important for me. & cognition & Valuing \\
\hline Q3 & $\begin{array}{l}\text { I feel very pleased with myself when I really understand } \\
\text { what I am taught at school. }\end{array}$ & & Mastery orientation \\
\hline Q4 & $\begin{array}{l}\text { Before I start an assignment I plan out how I am } \\
\text { going to do it. }\end{array}$ & $\begin{array}{l}\text { Adaptive } \\
\text { behaviour }\end{array}$ & Planning \\
\hline Q5 & $\begin{array}{l}\text { When I study I usually study in places where I } \\
\text { can concentrate. }\end{array}$ & & Task management \\
\hline Q6 & $\begin{array}{l}\text { If I cannot understand my schoolwork at first, I keep } \\
\text { going over it until I understand it. }\end{array}$ & & Persistence \\
\hline Q7 & I'm often unsure how I can avoid doing poorly at school. & Maladaptive & Uncertain control \\
\hline Q8 & $\begin{array}{l}\text { I sometimes do not study very hard before exams so I } \\
\text { have an excuse if I don't do as well as I hoped. }\end{array}$ & factors & Self-handicapping \\
\hline Q9 & I often feel like giving up at school. & & Disengagement \\
\hline Q10 & My parents push me to be the best I can be at school. & Parent influence & Encouragement \\
\hline Q11 & $\begin{array}{l}\text { My parents make me feel good if my school marks } \\
\text { are good }\end{array}$ & & Encouragement \\
\hline Q12 & $\begin{array}{l}\text { My parents allow me to do certain things if my school } \\
\text { marks are good (e.g. see friends, give me money) }\end{array}$ & & Encouragement \\
\hline Q13 & My friends treat me well & Peer influence & Encouragement \\
\hline Q14 & My friends will help me if I need it & & Encouragement \\
\hline Q15 & My teachers really care about me & Teacher influence & Encouragement \\
\hline Q16 & Teachers at school push me to be the best I can be & & Encouragement \\
\hline Q17 & I get a lot of encouragement at school & & Encouragement \\
\hline
\end{tabular}

was explained along with its anonymity. Replies were given to questions prior to a request for participants to voluntarily complete a paper version of the survey to the extent to which they felt comfortable. With few exceptions, all students in attendance chose to take the survey. Anonymity was guaranteed by not collecting any personal information that could reveal the identity of the participants. Ethical approval for the study was provided by the two universities to which the researchers were affiliated and followed principals and ethical guidelines of both The British Educational Research Association (BERA 2018) and The British Psychological Society (BPS 2018).

\section{Data Analysis}

Since this was the first application of the engagement survey in a former Soviet Union context, the following 3-step procedure was carried out. First, a principal component analysis (PCA) with varimax rotation and Kaiser normalization was performed using SPSS v24. The number of factors to retain was determined using multiple criteria, including Kaiser's criterion (eigenvalues $>1$ ), scree test, parallel analysis, and theoretical interpretation of the factor solution. Descriptive, reliability, and correlation analyses of the components extracted were carried out.
Second, a confirmatory factor analysis (CFA) was executed to test the fit of the model derived from the principal component analysis to the data using AMOS v25. Maximum likelihood was the method of estimation used for the model. Several measures of fit were used, as the $\chi^{2}$ test, which is the standard statistical test for goodness of fit is very sensitive to distributional misspecification with large samples sizes (Bentler and Bonett 1980). Thus, several fit indices encompassing absolute as well as incremental fit were considered given $\mathrm{Hu}$ and Bentler's (1999) recommendation that a combination presentation strategy was more likely to lead to a satisfactory decision about overall model fit given that their simulation work revealed that different indices behave more or less adequately dependent on sample size and distribution. Partly determined by availability within the software, indices of absolute fit considered were the root mean square error of approximation (RMSEA) and the Goodness-of-fit index (GFI). Indices of incremental fit included the Tucker-Lewis index (TLI) and the Comparative fit index (CFI). According to Schreiber et al. (2006), values approaching RMSEA < .06, and values $>.95$ on the TLI, CFI, and GFI indicate a good fit and $>.90$ for an adequate fit, and this combination of indices generates reasonable confidence in an overall judgement of model fit. 
Third, a series of four one-way between-groups multivariate analysis of variance (MANOVA) was conducted to examine the effect of some demographic (i.e., gender, grade) and contextual (i.e., geographic location, type of school) variables on the school engagement subscales. Preliminary assumption testing was conducted for all analyses to check violations for normality, linearity, univariate and multivariate outliers, homogeneity of variance-covariance matrices, and multicollinearity. To account for the multiple comparisons, adjusted Bonferroni correction at the $p<.008$ was used to interpret significant differences in the tests of betweensubjects effect. Effect sizes were calculated using the eta square statistic.

\section{Findings}

\section{Principal Component Analysis (PCA)}

The Bartlett's test of sphericity and the Kaiser-Meter-Olkin (KMO) test of sampling adequacy were used to determine the appropriateness of the data for principal component analysis in the school engagement scale. The KMO value was .841 and the Bartlett's test was significant $\left(\chi^{2}=7411.04 ; d f=136\right.$; $p<.001$ ), suggesting that the data was appropriate for principal component analysis. The analysis yielded five components with eigenvalue greater than 1.0, which accounted for $57.87 \%$ of the total variance. However, based on a careful examination of the scree plot, and substantive considerations regarding the structure and interpretability of the four- to six-component solutions, the six-component solution was considered the best to interpret the scores in the sample, which accounted for $63.49 \%$ of the total variance. Table 3 presents the factor loadings of the six-component solution, together with the eigenvalues and the variance explained by each component. All items loaded on the expected component with coefficients ranging from .52 to .86 . Based on the item loadings, components were interpreted as teacher support (component 1), adaptive cognition (component 2), adaptive behaviour (component 3), peer support (component 4), maladaptive factors (component 5), and parent support (component 6).

Total scores were then computed for each of the six subscales. Mean scores, standard deviations, internal consistency coefficients, and intercorrelations among subscales are presented in Table 4. The internal consistency coefficients were acceptable to good for the teacher support ( $\alpha=.82)$, peer support $(\alpha=.80)$, adaptive cognition $(\alpha=.67)$, and adaptive behaviour $(\alpha=.63)$ subscales, but low for maladaptive factors $(\alpha=.55)$ and parent support $(\alpha=.49)$ scales. No increases in alpha for any of the scales could have been achieved by eliminating items. All correlations among the components were statistically significant at the $p<.001$ level. The strongest correlations were found between adaptive behaviour and teacher support subscales $(r=.48)$ and between adaptive behaviour and adaptive cognition subscales $(r=.43)$.

\section{Confirmatory Factor Analysis (CFA)}

CFA using AMOS v25 was conducted for the model shown in Fig. 1. The model included the six first-order factors identified in the principal component analysis (adaptive cognition, adaptive behaviour, maladaptive factors, parent influence, peer influence, and teacher influence) and two correlated second-order factors (intrapersonal engagement and interpersonal engagement). Results indicated that there was a relatively good fit to the data, despite the significant value of the chi-square statistic $\left(\chi^{2}=587.25, d f=112, p<.001\right)$. Given that the $\chi^{2}$ is heavily dependent on sample size (Byrne 2016), as noted above, other goodness-of-fit indices were examined to evaluate the hypothesized model (see Table 5). Both absolute measures of fit indices (e.g., RMSEA and GFI) as well as comparative fit indices (e.g., TLI and CFI), reached the values indicated for relatively good fit to the data (Schreiber et al. 2006). Examination of the modification indexes and standardized residuals did not suggest alteration to the model. All indicators loaded significantly on their respective first-order factor and factor loadings to be greater than .50 , ranging .52 to .83 , except for three indicators $(\mathrm{Q} 8$, loading =.39; $\mathrm{Q} 12$, loading $=.39$; and $\mathrm{Q} 10$, loading $=.34$ ), which was not surprising considering the findings from the principal component analysis. The correlation between the two second-order factors was low $(r=.25)$, suggesting that these two factors represented distinct dimensions.

\section{Effect of Personal and Context Variables on School Engagement}

A series of one-way between-groups multivariate analysis of variance (MANOVA) was conducted to assess the effect of gender, grade, geographical location, and type of school on school engagement. Six dependent variables were used in all analyses: adaptive cognition, adaptive behaviour, maladaptive factors, parent support, peer support, and teacher support. The independent variables were gender (male, female), grade (9th-10th grade, 11th- 12th grade), geographic location (urban, rural), and type of school (selective urban, specialized urban, mainstream urban, large rural, small rural). Adjusted Bonferroni correction at the $p<.008$ was used to interpret significant differences in the tests of between-subjects effect. Preliminary assumption testing revealed a significant Box's M test $(p<.001)$ in the four MANOVAs, indicating a violation of homogeneity of covariance matrices. Therefore, Pillai's Trace test was used to interpret significant effects of the independent variables on the school engagement subscales. No other serious violations were noted.

Gender There was a statistically significant difference between males and females on the combined dependent 
Table 3 Principal component analysis

\begin{tabular}{|c|c|c|c|c|c|c|c|}
\hline & & \multicolumn{6}{|c|}{ Component } \\
\hline & & 1 & 2 & 3 & 4 & 5 & 6 \\
\hline Q1 & If I try hard, I believe I can do my schoolwork well. & & .79 & & & & \\
\hline Q2 & Learning at school is important for me. & & .52 & & & & \\
\hline Q3 & I feel very pleased with myself when I really understand what I am taught at school & & .74 & & & & \\
\hline Q4 & Before I start an assignment, I plan out how I am going to do it. & & & .80 & & & \\
\hline Q5 & When I study I usually study in places where I can concentrate. & & & .71 & & & \\
\hline Q6 & If I cannot understand my schoolwork at first, I keep going over it until I understand it. & & & .58 & & & \\
\hline Q7 & I'm often unsure how I can avoid doing poorly at school. & & & & & .73 & \\
\hline Q8 & $\begin{array}{l}\text { I sometimes do not study very hard before exams, so I have an excuse if I } \\
\text { don't do as well as I hoped. }\end{array}$ & & & & & .65 & \\
\hline Q9 & I often feel like giving up at school. & & & & & .75 & \\
\hline Q10 & My parents push me to be the best I can be at school. & & & & & & .60 \\
\hline Q11 & My parents make me feel good if my school marks are good & & & & & & .69 \\
\hline Q12 & $\begin{array}{l}\text { My parents allow me to do certain things if my school marks are good } \\
\text { (e.g. see friends, give me money) }\end{array}$ & & & & & & .75 \\
\hline Q13 & My friends treat me well. & & & & .86 & & \\
\hline Q14 & My friends will help me if I need it. & & & & .83 & & \\
\hline Q15 & My teachers really care about me. & .79 & & & & & \\
\hline Q16 & Teachers at school push me to be the best I can be. & .86 & & & & & \\
\hline Q17 & I get a lot of encouragement at school. & .77 & & & & & \\
\hline & Eigenvalue & 4.52 & 1.76 & 1.36 & 1.13 & 1.06 & 0.95 \\
\hline & $\%$ Variance explained & 26.60 & 10.34 & 8.02 & 6.65 & 6.24 & 5.62 \\
\hline
\end{tabular}

Factor loadings $<.40$ were removed

variables, $F(1,1594)=7.79, p<.001$; Pillai's Trace $=.029$, partial $\eta^{2}=.016$. When the results for the dependent variables were considered separately, the only difference to reach statistical significance was adaptive cognition $(p<.001$, partial $\left.\eta^{2}=.016\right)$. An inspection of the mean scores indicated that female students reported significantly higher levels of adaptive cognition $(M=4.40, S D=0.61)$ than male students $(M=$ $4.24, S D=0.65)$.

Grade The data were dichotomised in terms of students remaining in school versus those in their final year of school. There was a statistically significant difference between students in grades 9-10 and students in grades $11-12$ on the combined dependent variables, $F(1,1765)=7.12, p<.001$; Pillai's Trace $=.024$, partial $\eta^{2}=.024$. Tests of betweensubjects effect revealed statistically significant differences between the two groups on parent support $(p<.001$, partial $\eta^{2}=.009$ ). Students in grades 9-10 reported higher levels of parent support $(M=3.97, S D=0.68)$ than students in grades $11-12(M=3.84, S D=0.72)$.

Geographic Location The was a significant effect of geographic location on school engagement, $F(1,1581)=8.01$, $p<.001$; Pillai's Trace $=.030$, partial $\eta^{2}=.030$. Tests of
Table 4 Descriptive statistics and correlation matrix for latent variables

\begin{tabular}{lllllllll}
\hline & $\mathrm{M}$ & $\mathrm{SD}$ & $\alpha$ & 1 & 2 & 3 & 4 & 5 \\
\hline 1. Adaptive cognition & 4.33 & 0.63 & .67 & - & & & \\
2. Adaptive behaviour & 3.65 & 0.81 & .63 & $.43^{* * * *}$ & - & & \\
3. Maladaptive factors & 2.74 & 0.84 & .55 & $-.12^{* * * *}$ & $-.13^{* * *}$ & - & \\
4. Parent support & 3.94 & 0.69 & .49 & $.31^{* * * *}$ & $.23^{* * *}$ & $.08^{* * * *}$ & - & \\
5. Peer support & 4.26 & 0.76 & .80 & $.41^{* * * *}$ & $.34^{* * *}$ & $-.16^{* * * *}$ & $.20^{* * * *}$ & - \\
6. Teacher support & 3.70 & 0.93 & .82 & $.39^{* * * *}$ & $.48^{* * *}$ & $-.20^{* * *}$ & $.21^{* * *}$ & $.38^{* * *}$ \\
\hline
\end{tabular}

$* * * p<.001$ 
Fig. 1 Model of school engagement depicting a secondorder factor structure hypothesized to underlie the six first-order factors - all factor loadings are statistically significant $(p<.001)$

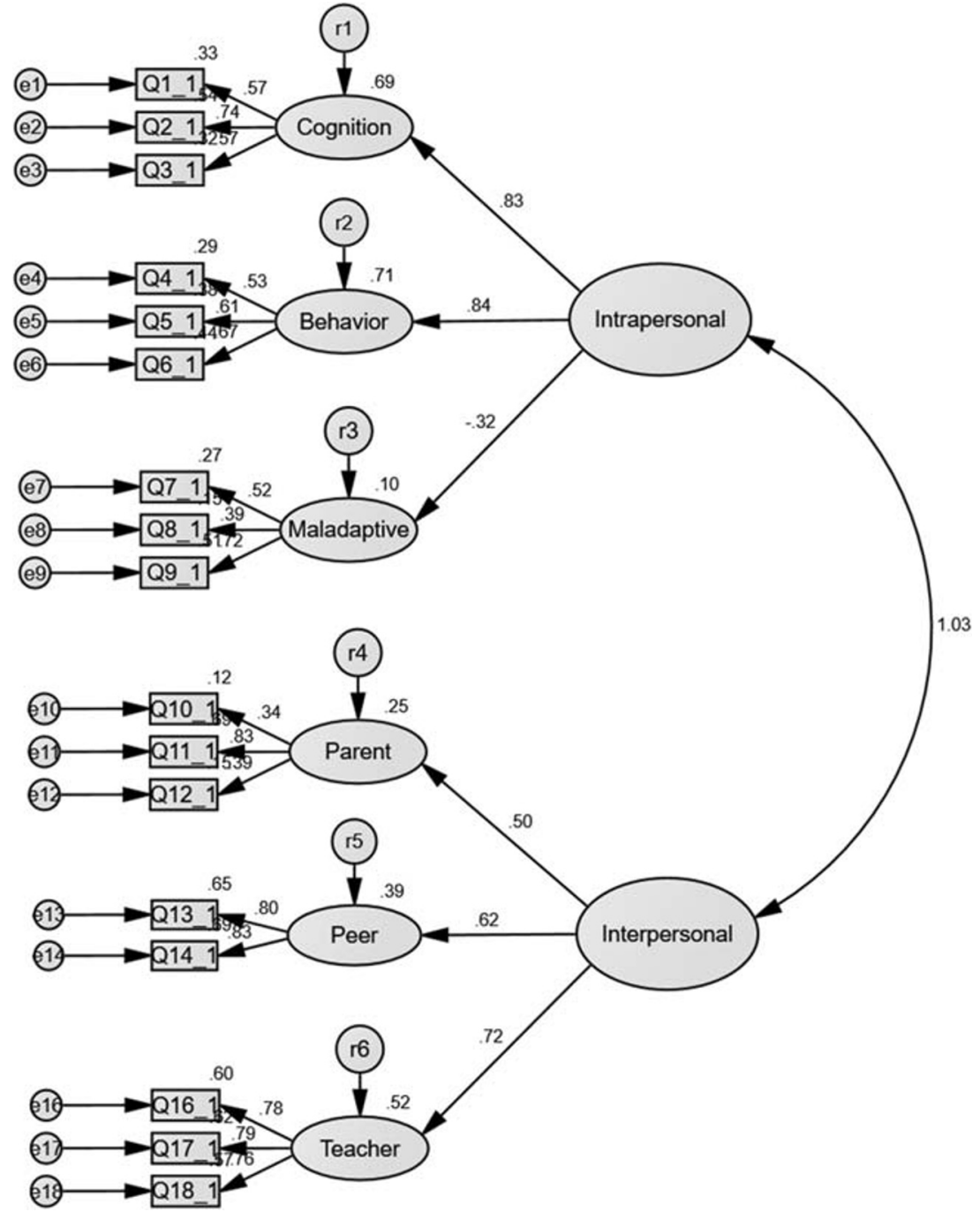

between-subjects effect revealed that rural students demonstrated higher levels of school engagement compared to urban students on adaptive behaviour $\left(p<.001\right.$, partial $\left.\eta^{2}=.013\right)$, peer support $\left(p<.001\right.$, partial $\left.\eta^{2}=.008\right)$, and teacher support $\left(p<.001\right.$, partial $\left.\eta^{2}=.021\right)$.

Table 5 Goodness-of-fit indexes

\begin{tabular}{lll}
\hline & CFA & $\begin{array}{l}\text { Criteria for satisfactory } \\
\text { level of fit }{ }^{1}\end{array}$ \\
\hline Chi-square & $587.24, p=.000$ & $p>.05$ \\
Degrees of freedom & 112 & - \\
RMSEA & .049 & $<.06$ \\
TLI & .921 & $>.95$ \\
GFI & .961 & $>.95$ \\
CFI & .935 & $>.95$ \\
\hline
\end{tabular}

RMSEA Root mean square error of approximation, TLI Tucker-Lewis index, GFI Goodness-of-fit index, CFI Comparative fit index. ${ }^{I}$ Schreiber et al. (2006)
Type of School There was a statistically significant difference in school engagement based on type of school, $F(24,7040)=$ 9.57, $p<.001$; Pillai's Trace $=.127$, partial $\eta^{2}=.032$. Separate univariate ANOVAs on the outcome variables revealed significant differences in school engagement between the five groups on adaptive cognition, $F(4,1766)=4.16 ; p=.002$, partial $\eta^{2}=.009$; adaptive behaviour $F(4,1766)=26.76$; $p<.001$, partial $\eta^{2}=.057$; maladaptive factors, $F(4$, $1766)=4.85 ; p=.001$, partial $\eta^{2}=.011$; peer support, $F(4$, 1766) $=6.74 ; p<.001$, partial $\eta^{2}=.015$; and teacher support, $F(4,1766)=36.65 ; p<.001$, partial $\eta^{2}=.077$. In general, post-hoc comparisons using the Tukey HSD test indicated that students in selective and specialized schools (i.e., lyceums and gymnasiums) reported lower levels of engagement with school compared to students in urban mainstream and rural schools (large and small). Thus, students in specialized schools scored significantly lower than their peers in urban mainstream, large village, and small village schools on adaptive behaviour $(p<.001)$ and obtained higher scores than students in urban mainstream $(p<.001)$ and large village schools 
( $p=.002)$ on maladaptive factors. Although students attending selective schools reported higher levels of adaptive cognition than students in specialized schools $(p=.006)$, they also reported lower adaptive behaviour than students in urban mainstream, large village, and small village schools $(p<.001$ for all group comparisons). Similar results were found for self-reported social support. First, students in specialized schools indicated lower levels of peer support compared to students in large village $(p<.001)$ and small village schools ( $p=.004)$, and lower levels of teacher support than all other groups ( $p<.001$ for all group comparisons). Second, NIS students reported greater teacher support than students in specialized schools $(p=.001)$ but significantly lower support from their teachers when compared to that reported by students in urban mainstream $(p=.002)$, large village $(p=.001)$, and small village $(p=.001)$. No statistically significant differences in school engagement nor social support were found between students in mainstream, large rural, and small rural schools.

\section{Discussion}

The first inference that can be drawn from this work is that an individualised model of school engagement used in Western cultural settings (Martin 2004) can be improved for use in a former Soviet Union country with the addition of measures of self-reported social support. Adding the influence of positive social influences from peers, teachers and parents results in a validated model and useful tool to measure school engagement in a former Soviet Union country as it transitions towards a more individualised model of education. There is clear evidence that students' engagement in education in Kazakhstan is drawn from two sources: intra-personal and inter-personal elements. At the level of the individual, the model suggests positive cognitions and behaviours have equal importance, with some lesser influence from maladaptive behaviours. Overall engagement is supported by positive inputs, in order of importance from teachers, peers and, finally but not insignificantly, parents. There are limitations in the way the influences of parents are modelled in this research and revisiting the items that provide measures of this are a clear improvement that could be made in the overall representation of school engagement. This is a significant cultural shortcoming in that kin relationships are of paramount importance for young people in Kazakhstan with $81 \%$ of young people considering themselves having a responsibility towards the wider family compared to $51 \%$ feeling responsible for themselves (Biyekenova et al. 2016).

There are additional areas of improvement in the model in that it consists of merely 17 items and whilst this confers ease of use and high completion rates, it means that additional items could be introduced to provide better reliability in the representation of some factors. More specifically, items that relate to peer influences and parental support could be improved and increased in number. The sub-scale of maladaptive behaviours would also bear further consideration in order to improve its reliability.

Although there are influences on school engagement included in the model from those with whom students have most immediate and frequent social contact such as peers, parents and teachers, the model does not extend to wider social influences. Thus, it is limited in its ambition to fully represent the ongoing mindset of a collective society as still evident by strong media interest in the best performing students receiving 'Altyn Belgi' (gold pendant) as a badge of honour for their school career and examination results or as winners of Olympiads (Winter et al. 2014b). Indeed, the role of Olympiads in Kazakhstan continues to press and winners of these from school to regional to Republican levels and especially at international competitions are lauded by their communities at each and every level (egov 2019). Certainly, it has been a stated aim of the First President of Kazakhstan in every decree since independence that education is a priority and the future of Kazakhstan depends on education to build and secure Kazakhstan's future, summarised and phrased as 'to increase competitiveness of education and development of human capital through ensuring access to quality education for sustainable economic growth' (Akorda 2019). Success at international Olympiads publicly displays and honours this aim in the tradition of competative Soviet acheivements. Hence, an addition to the scale here could be to encapsulate and measure the effect on young people of a national aim for evidenced improvements in education. These could be through media reporting in terms of performances in international largescale assessments or, at a more individual level, how an ethos of competition in education affects them through pressures to sit entry examinations for selection into schools for gifted pupils and participation in public competitions.

There is a general trend for female students to report higher levels of school engagement than males, consistent with other evidence from across Europe, North America and Asia (Lam et al. 2012). Coupled to this, there is considerable evidence that male students demonstrate more behavioural problems at school and lower levels of school compliance (Brewster and Bowen 2004; Wang and Eccles 2012). The data presented here confirm that young women in Kazakhstan also have more positive engagement than their male counterparts. This suggests that, although there is no difference in compliance through observable behaviours between young men and women in Kazakhstan, young men are less convinced about the purpose of school and, relatedly, about higher education as a next move. This is an area for further research and reiterates the need to compare both observable behaviour and attitudes against beliefs. At present, the enrolment rate of women in higher education in Kazakhstan is higher than males: $53.4 \%$ 
of the cohort are female (OECD 2017a). Whether this is an artefact of alternative opportunities for men vs women or any other causal factors outside school is unexplored but clearly the poorer development of cognitive engagement in young men in Kazakhstan is a topic worthy of concern and future study.

The reduced levels of overall school engagement found in older participants is consistent with the extant literature on school engagement and can be construed as an agedependent effect (Fernández-Zabala et al. 2016; Janosz et al. 2008; Simons-Morton and Crump 2003; Wang and Eccles 2012; Witherspoon and Ennett 2011). That said, the support of Kazakhstani parents (albeit the least influential of the external factors) diminished significantly between the younger and older student groups and this may be an important trend. One explanation for this could be the inter-generational differences in experiences as the country transforms the curriculum and content of education. Hence, the potentially limited assistance parents could provide in the new system. There is a relative paucity of literature on the effect of parental involvement in the latter stages of schooling, compared to parental involvement in the pre-school and early years (Avvisati et al. 2010). However, one aspect that has emerged is the pivotal role of student voice (Rudduck and Flutter 2000) and the growing need for negotiation by adolescent students themselves in-between their home and school environments so that the level of parental involvement is commensurate with students' own desire for such support (Edwards and Alldred 2000). It is a fine line between encouragement and perceived pressure and interference from parents.

There could be several explanations as to why students in rural schools are more engaged than those in urban schools. The most obvious reasons are that a sense of belongingness is higher, and class-sizes are smaller so more individualised attention at school is possible in such cases (Blatchford et al. 2011; Finn 1993; Slaten et al. 2016). There are more close and extended kin in the school; quality friendships from stable cohorts are more likely; family circumstances are well understood by teachers and vice versa, with a sense of community permeating from the village to the school. This supports international findings that even an easy and familiar walk from home to school against a bus-ride may profit a sense of belonging (Anderman 2002). Furthermore, stronger personal relationships may enable peers, teachers, family and the wider community to spot early indications of disengagement and to offer support. However, it is important to note that students' cognitions, sources of social encouragement and maladaptive behaviours do not differ significantly between rural and urban locations, but their adaptive behaviours do. Given the items that form this measure, it may be that rural students make less academic progress simply because they possess lessdeveloped skills to plan, pay attention to and persevere with independent work. This could be due to a less developed sense of personal control or immaturity. Certainly, it is an issue that could be explored further. Perhaps the close relationships that rural students have with teachers may benefit relationships and encourage greater school engagement but, in parallel, may also hinder independent learning. As seen elsewhere (Furrer and Skinner 2003), the tension between effortful learning, personal control and relatedness is unclear especially as they relate to academic performance.

Another key finding is that different types of school in Kazakhstan have different levels of school engagement. Specialised urban schools and selective schools have students with the least positive attitudes towards education. It is wellknown that high-stakes testing penalises some aspects of learning, particularly the vicarious and more enjoyable journeys of exploration that foster intrinsic motivation. More selective schools may have a stronger emphasis on performativity and maintaining their strong academic reputations, which may impact negatively on student engagement (see Ryan and Sapp (2005) for a full discussion of this). This too merits further research.

\section{Limitations and Future Directions}

There are several limitations to this study. Firstly, the data collected could usefully be directly linked to academic performance to explore the extent to which academic achievement and school engagement interact. Unfortunately, this ambition may not be as straightforward as one would wish since there are limited national performance measures in Kazakhstan to set school engagement against academic outcomes for any of the grades prior to the final grade of Grade 11. Even then, the national test in Grade 11 has many flaws that need remedy before it may become a 'more credible and valid instrument' to signal learning (OECD 2017b: 131). That said, correlates between academic outcomes using school examinations and engagement measures could inform to some extent on a school-by-school basis to give insight on local conditions that affect learning outcomes.

Secondly, the research would have benefited from a broader set of measures to capture the attitudes of young people in Kazakhstan regarding their future and career aspirations. Questions looking at retention and projected pathways in education were piloted in a preliminary version of this scale. However, this led to a diverse set of reasons for transferring or exiting from the current school that did not simply rely on school engagement. For example, demographic, cultural and linguistic reasons for switches in educational pathways included lack of access to upper grades from a remote village location, a need to work in a family business or insufficient numbers to form a viable class of students taught with a certain medium of instruction. These are clearly situational factors that can vicariously affect engagement beyond psychological 
influences. Thus, recognition of additional variables may be useful in any future model to address the variety of school circumstances found in Kazakhstan. Finding a means to control for local conditions would secure fuller external and predictive validity of the psychological model as it performed against later educational choices. However, without recognising external factors and uneven opportunities for students, hypothesising purely psychological influences affected educational choices would be inappropriate for Kazakhstan.

Thirdly, a more structured approach to obtaining information on what young people, parents and teachers believe are the purposes of school would have improved the analysis and allowed comparison across groups and group influences. Exploring young people's attitudes towards autonomy and how they differ from those of their parents would have helped explore potential tensions resulting from differences in intergenerational expectations and most likely improved the parental influence component within the model.

Finally, despite the limitations discussed above, the development of a short (17-item) tool is a first step in facilitating further research on school engagement in former Soviet Union and other societies. Enhancing the understanding of the interaction between individual and social influence contributions from important others with a usable model of school engagement in Kazakh and Russian languages can give measure to those developing student-centred learning as a new paradigm in such contexts.

Acknowledgements The authors would like to acknowledge and thank The British Council and Al-Farabi Foundation through the Newton Fund, Institutional Links Programme (Reference: 172734464) for the funding of this research.

Many participants contributed generously to the research including various stakeholders and the numerous psychologists, teachers, students and other staff at the 55 schools that the research team visited. The research team are extremely grateful for the valuable support, courteous and helpful responses they received and would like their gratitude noted.

\section{Compliance with Ethical Standards}

Conflict of Interest On behalf of all authors, the corresponding author states that there is no conflict of interest between the work presented here and any authors' affiliation or the source of funding.

Ethical Approval and Informed Consent The research was approved prior to data collection by the Ethics Committee of INSTITUTION 1 and Informed Consent was obtained from all participants prior to their involvement. A Participant Information Sheet was provided to participants in their language of chouice to assist in this.

Open Access This article is licensed under a Creative Commons Attribution 4.0 International License, which permits use, sharing, adaptation, distribution and reproduction in any medium or format, as long as you give appropriate credit to the original author(s) and the source, provide a link to the Creative Commons licence, and indicate if changes were made. The images or other third party material in this article are included in the article's Creative Commons licence, unless indicated otherwise in a credit line to the material. If material is not included in the article's
Creative Commons licence and your intended use is not permitted by statutory regulation or exceeds the permitted use, you will need to obtain permission directly from the copyright holder. To view a copy of this licence, visit http://creativecommons.org/licenses/by/4.0/.

\section{References}

Adler, M. J. (1982). The Paideia proposal: An educational manifesto. New York: Simon \& Schuster.

Ajzen, I., \& Fishbein, M. (1980). Understanding attitudes and predicting social behavior. Englewood Cliffs: Prentice-Hall.

Akorda. (2019). The strategy for development of the Republic of Kazakhstan until the year 2030. The Republic of Kazakhstan, NurSultan, "Akorda" Presidential Residence. http://www.akorda.kz/en/ official_documents/strategies_and_programs Accessed 12 December 2019.

Alexander, R. J. (2012). Moral panic, miracle cures and educational policy: What can we really learn from international comparison? Scottish Educational Review, 4-21.

Anderman, E. M. (2002). School effects on psychological outcomes during adolescence. Journal of Educational Psychology, 94(4), 795809. https://doi.org/10.1037/0022-0663.94.4.795.

Annunziata, D., Hogue, A., Faw, L., \& Liddle, H. A. (2006). Family functioning and school success in at-risk, inner-city adolescents. Journal of Youth and Adolescence, 35(1), 100-108.

Antonowicz, L. (2013). Identification and monitoring of out-of-school children and dropping-out of students: Kazakhstan. Astana, Kazakhstan: The UN Children's Fund (UNICEF) in the Republic of Kazakhstan. https://www.unicef.org/kazakhstan/media/1466/file. Accessed 11 June 2019.

Appleton, J. J., Christenson, S. L., Kim, D., \& Reschly, A. L. (2006). Measuring cognitive and psychological engagement: Validation of the student engagement instrument. Journal of School Psychology, 44(5), 427-445.

Appleton, J. J., Christenson, S. L., \& Furlong, M. J. (2008). Student engagement with school: Critical conceptual and methodological issues of the construct. Psychology in the Schools, 45(5), 369-386.

Astana Times. (2019), Kazakh graduating high school students undertaking Unified National Testing June 20-30. Published online 24 June 2019 at https://astanatimes.com/2019/06/kazakh-graduatinghigh-school-students-undertaking-unified-national-testing-june-2030/. Accessed 12 December 2019.

Avvisati, F., Besbas, B., \& Guyon, N. (2010). Parental involvement in school: A literature review. Revue d'économie Politique, 120(5), 759-778. https://doi.org/10.3917/redp.205.0759.

Bartle-Haring, S., Younkin, F. L., \& Day, R. (2012). Family distance regulation and school engagement in middle-school-aged children. Family Relations, 61(2), 192-206.

Bear, G. G., Yang, C., Chen, D., He, X., Xie, J.-S., \& Huang, X. (2018). Differences in school climate and student engagement in China and the United States. School Psychology Quarterly, 33(2), 323-335. https://doi.org/10.1037/spq0000247.

Bentler, P. M., \& Bonett, D. G. (1980). Significance tests and goodness of fit in the analysis of covariance structures. Psychological Bulletin, 88, 588-606 https://web-a-ebscohost-com.ezp.lib.cam.ac.uk/ehost/ pdfviewer/pdfviewer?vid=3\&sid=356709ef-c92b-424d-9874$1 \mathrm{cb} 3 \mathrm{~d} 3 \mathrm{c} 557 \mathrm{fb} \% 40$ sdc-v-sessmgr02.

BERA (2018). Ethical Guidelines for Educational Research, fourth edition. London: British Educational Research Association. https:// www.bera.ac.uk/researchers-resources/publications/ethicalguidelines-for-educational-research-2018. Accessed 21 May 2019. 
Biyekenova, N. Z., Abdiraiymova, G. S., Kenzhakimova, G. A., Shaukenova, Z. K., \& Senuk, Z. V. (2016). Value system of students of the Republic of Kazakhstan as a special social and cultural group. International Journal of Environmental and Science Education, 11(9), 2481-2494. https://doi.org/10.12973/ijese.2016.701a.

Blatchford, P., Bassett, P., \& Brown, P. (2011). Examining the effect of class size on classroom engagement and teacher-pupil interaction: Differences in relation to pupil prior attainment and primary vs. secondary schools. Learning and Instruction, 21(6), 715-730. https://doi.org/10.1016/j.learninstruc.2011.04.001.

Boekaerts, M. (1993). Being concerned with well-being and with learning. Educational Psychologist, 28, 148-167.

Bokayev, B. (2016). The Improvement of Quality of Primary and Secondary Education in Kazakhstan. Published by Department of Strategy, The Ministry of Education and Science of the Republic of Kazakhstan. Cornell Institute for Public Affairs- Cornell University. Policy Report: https://ecommons.cornell.edu/handle/1813/45565. Accessed 21 March 2019.

Bowen, G. L., Rose, R. A., Powers, J. D., \& Glennie, E. J. (2008). The joint effects of neighborhoods, schools, peers, and families on changes in the school success of middle school students. Family Relations, 57(4), 504-516.

BPS. (2018). Code of ethics and conduct. London: British Psychological Society. Resource document: https://www.bps.org.uk/news-andpolicy/bps-code-ethics-and-conduct. Accessed 21 May 2019.

Brewster, A. B., \& Bowen, G. L. (2004). Teacher support and the school engagement of Latino middle and high school students at risk of school failure. Child and Adolescent Social Work Journal, 21(1), 47-67.

Bridges, D. (2014). Education Reform and Internationalisation: The Case of School Reform in Kazakhstan (Cambridge education research). Cambridge: Cambridge University Press.

Bronfenbrenner, U. (1979). Contexts of child rearing: Problems and prospects. The American Psychologist, 34, 844-850.

Buhs, E. S., \& Ladd, G. W. (2001). Peer rejection as antecedent of young children's school adjustment: An examination of mediating processes. Developmental Psychology, 37(4), 550-560.

Buhs, E. S., Ladd, G. W., \& Herald, S. L. (2006). Peer exclusion and victimization: Processes that mediate the relation between peer group rejection and children's classroom engagement and achievement? Journal of Educational Psychology, 98(1), 1-13.

Byrne, B. M. (2016). Structural equation modeling with AMOS: Basic concepts, applications, and programming (3rd ed.). New York: Routledge. https://doi.org/10.4324/9781315757421.

Ceci, S. J., \& Williams, W. M. (1997). Schooling, intelligence, and income. American Psychologist, 52(10), 1051-1058. https://doi.org/ 10.1037/0003-066X.52.10.1051

Christenson, S. L., \& Thurlow, M. L. (2004). School dropouts: Prevention considerations, interventions, and challenges. Current Directions in Psychological Science, 13, 36-39.

Cummings, E. M., Davies, P. T., \& Campbell, S. B. (2000). Developmental psychopathology and family process: Theory, research, and clinical implications. New York: Guilford Press.

Daly, B. P., Shin, R. Q., Thakral, C., Selders, M., \& Vera, E. (2009). School engagement among urban adolescents of color: Does perception of social support and neighbourhood safety really matter? Journal of Youth and Adolescence, 38(1), 63-74.

Edwards, R., \& Alldred, P. (2000). A typology of parental involvement in education centring on children and young people: Negotiating familialisation, institutionalisation and individualism. British Journal of Sociology of Education, 21(3), 435-455.

egov. (2019). Republican Olympiads and competitions for schoolchildren. Electronic government of the Republic of Kazakhstan. https://egov.kz/cms/en/articles/2Frepublic olimp. Accessed 12 December 2019.
ESP. (2007). Monitoring School Dropouts: Albania, Kazakhstan, Latvia, Mongolia, Slovakia, and Tajikistan. Budapest: Education support program (ESP) of the Open Society Institute. New York: Open Society Institute.

Fernández-Zabala, A., Goñi, E., Camino, I., \& Zulaika, L. M. (2016). Family and school context in school engagement. European Journal of Education and Psychology, 9(2), 47-55.

Finn, J.D. (1993). School engagement and students at risk. Washington, DC: National Center for education statistics. http://files.eric.ed.gov/ fulltext/ED362322.pdf. Accessed 21 March 2019.

Fredricks, J. A., Blumenfeld, P. C., \& Paris, A. H. (2004). School engagement: Potential of the concept, state of the evidence. Review of Educational Research, 74(1), 59-109. https://doi.org/10.3102/ 00346543074001059.

Furrer, C., \& Skinner, E. (2003). Sense of relatedness as a factor in children's academic engagement and performance. Journal of Educational Psychology, 95(1), 148-162.

Green, J., Liem, G. A. D., Martin, A. J., Colmar, S., Marsh, H. W., \& McInerney, D. (2012). Academic motivation, self-concept, engagement, and performance in high school: Key processes from a longitudinal perspective. Journal of Adolescence, 35(5), 1111-1122. https://doi.org/10.1016/j.adolescence.2012.02.016.

Hallinan, M. T. (2008). Teacher influences on students' attachment to school. Sociology of Education, 81(3), 271-283.

Hartley, M., Gopaul, B., Sagintayeva, A., \& Apergenova, R. (2016). Learning autonomy: Higher education reform in Kazakhstan. Higher Education, 72(3), 277-289. https://doi.org/10.1007/ s10734-015-9953-z.

Hernández-Torrano, D., \& Tursunbayeva, X. (2016). Are teachers biased when nominating students for gifted services? Evidence from Kazakhstan. High Ability Studies, 27(2), 165-177. https://doi.org/ 10.1080/13598139.2015.1108187.

Hu, L., \& Bentler, P. M. (1999). Cutoff criteria for fit indexes in covariance structure analysis: Conventional criteria versus new alternatives. Structural Equation Modeling, 6, 1-55. https://doi.org/10. 1080/10705519909540118.

Huebner, S. (2001). Multidimensional students' life satisfaction scale. University of South Carolina, Department of Psychology, Columbia, SC, 29208.

IAC. (2019). Statistics of Education System Republic of Kazakhstan National Collection 2019. Astana, Kazakhstan: JSC Informational Analytical Center. Resource document. http://iac.kz/sites/default/ files/nacionalnyy_sbornik_2018-2019.pdf Accessed 11 Feb 2019.

International Test Commission. (2017). The ITC Guidelines for Translating and Adapting Tests (Second edition). Resource document. https://www.intestcom.org/files/guideline_test_adaptation 2ed.pdf. Accessed 12 May 2019.

Janosz, M., Archambault, I., Morizot, J., \& Pagani, L. S. (2008). School engagement trajectories and their differential predictive relations to dropout. Journal of Social Issues, 64(1), 21-40. https://doi.org/10. 1111/j.1540-4560.2008.00546.x.

Kelly, S., \& Zhang, Y. (2016). Teacher support and engagement in math and science: Evidence from the high school longitudinal study. The High School Journal, 99, 141-165.

Kulakhmetova, A. (2017). Evolving notions of childhood: an example of Kazakhstan, thesis submitted for $\mathrm{PhD}$ at University of Cambridge. Published online at https://core.ac.uk/download/pdf/151208274. pdf. Accessed 11 June 2019.

Lam, S. F., Yim, P. S., Law, J. S. F., \& Cheung, R. W. Y. (2004). The effects of competition on achievement motivation in Chinese classrooms. British Journal of Educational Psychology, 74(2), 281-296.

Lam, S., Jimerson, S., Kikas, E., Cefai, C., Veiga, F. H., Nelson, B., Hatzichristou, C., Polychroni, F., Basnett, J., Duck, R., Farrell, P., Liu, Y., Negovan, V., Shin, H., Stanculescu, E., Wong, B. P. H., Yang, H., \& Zollneritsch, J. (2012). Do girls and boys perceive themselves as equally engaged in school? The results of an 
international study from 12 countries. Journal of School Psychology, 50(1), 77-94. https://doi.org/10.1016/j.jsp.2011.07.004.

Liem, G. A. D., \& Martin, A. J. (2012). The motivation and engagement scale: Theoretical framework, psychometric properties, and applied yields. Australian Psychologist, 47(1), 3-13. https://doi.org/10. 1111/j.1742-9544.2011.00049.x.

Martin, A. J. (2004). School motivation of boys and girls: Differences of degree, differences of kind, or both? Australian Journal of Psychology, 56, 133-146.

Martin, A. J. (2007). Examining a multidimensional model of student motivation and engagement using a construct validation approach. British Journal of Educational Psychology, 77, 413-440.

Martin, A. J. (2016). Using load reduction instruction (LRI) to boost motivation and engagement. Leicester: British Psychological Society.

Martin, A. J., \& Hau, K.-T. (2010). Achievement motivation amongst Chinese and Australian school students: Assessing differences of kind and differences of degree. International Journal of Testing, 10, 274-294.

Martin, A. J., Ginns, P., \& Papworth, B. (2017). Motivation and engagement: Same or different? Does it matter? Learning and Individual Differences, 55, 150-162. https://doi.org/10.1016/j.lindif.2017.03. 013

McDermott, P. A., Mordell, M., \& Stolzfus, J. C. (2001). The organization of student performance in American schools: Discipline, motivation, verbal learning, and nonverbal learning. Journal of Educational Psychology, 93, 65-76.

Mead, M. A., \& Silova, I. (2013). Literacies of (post)socialist childhood: Alternative readings of socialist upbringings and neoliberal futures. Globalisation, Societies and Education, 11(2), 194-222. https://doi. org/10.1080/14767724.2013.783314.

MoJRK. (2012). Resolution of the Government of the Republic of Kazakhstan dated 03.30.2012 No. 390 (changes dated 05.13.2016 no. 289. Astana: Republican Legal Information Center of the Ministry of Justice of the Republic Kazakhstan.

Musina, Z. (2015). Development perspectives of rural schools. Astana: Informational Analytical Center (IAC). Resource document http:// iac.kz/en/publishing/development-perspectives-rural-schools-0. Accessed 22 May 2019.

OECD. (2017a). Gender policy delivery in Kazakhstan, OECD Public Governance Reviews, Paris: OECD Publishing. Resource document https://doi.org/10.1787/9789264280359-en. Accessed 22 May 2019.

OECD (2017b). Higher education in Kazakhstan 2017, Reviews of National Policies for Education, OECD Publishing, Paris, https:// doi.org/10.1787/9789264268531-en. Accessed 15 Feb 2020.

OECD. (2018). Education policy outlook: Kazakhstan, OECD education policy outlook series. Resource document. Paris: OECD Publishing http://www.oecd.org/education/Education-Policy-OutlookCountry-Profile-Kazakhstan-2018.pdf. Accessed 22 May 2019.

OECD/The World Bank. (2015). OECD reviews of school resources: Kazakhstan 2015. Paris: OECD Publishing. https://doi.org/10. 1787/9789264245891-en.

Oka, N. (2018). Grades and degrees for Sale: Understanding informal exchanges in Kazakhstan's education sector. Problems of PostCommunism, 66, 329-341. https://doi.org/10.1080/10758216. 2018.1468269.

Osterman, K. (2000). Students' need for belonging in the school community. Review of Educational Research, 70(3), 323-367.

$\mathrm{Ou}, \mathrm{S} . \mathrm{R}$. (2005). Pathways of long-term effects of an early intervention program on educational attainment: Findings from the Chicago longitudinal study. Journal of Applied Developmental Psychology, 26(5), 578-611. https://doi.org/10.1016/j.appdev.2005.06.008.

Perdue, N. H., Manzeske, D. P., \& Estell, D. B. (2009). Early predictors of school engagement: Exploring the role of peer relationships.
Psychology in the Schools, 46(10), 1084-1097. https://doi.org/10. 1002/pits.20446.

Perry, J. C., Liu, X., \& Pabian, Y. (2010). School engagement as a mediator of academic performance among urban youth: The role of career preparation, parental career support, and teacher support. The Counseling Psychologist, 38(2), 269-295.

Petrides, K. V., Frederickson, N., \& Furnham, A. (2004). The role of trait emotional intelligence in academic performance and deviant behavior at school. Personality and Individual Differences, 36(2), 277293. https://doi.org/10.1016/S0191-8869(03)00084-9.

Reininger, B., Evans, A. E., Griffin, S. F., Valois, R. F., Vincent, M. L., Parra-Medina, D., et al. (2003). Development of a youth survey to measure risk behaviors, attitudes and assets: Examining multiple influences. Health Education Research, 18(4), 461-476. https:// doi.org/10.1093/her/cyf046.

Rigi, J. (2003). The conditions of post-soviet dispossessed youth and work in Almaty, Kazakhstan. Critique of Anthropology, 23(1), 3549. https://doi.org/10.1177/0308275X03023001811.

Rodríguez-Fernández, A., Droguett, L., \& Revuelta, L. (2012). School and personal adjustment in adolescence: The role of academic selfconcept and perceived social support. Revista de Psicodidáctica, 17(2), 397-414.

Roorda, D. L., Koomen, H. M., Spilt, J. L., \& Oort, F. J. (2011). The influence of affective teacher-student relationships on students' school engagement and achievement: A meta-analytic approach. Review of Educational Research, 81(4), 493-529.

Rudduck, J., \& Flutter, J. (2000). Pupil participation and pupil perspective: 'Carving a new order of experience. Cambridge Journal of Education, 30(1), 75-89. https://doi.org/10.1080/ 03057640050005780 .

Ryan, R. M., \& Deci, E. L. (2000). Self-determination theory and the facilitation of intrinsic motivation, social development and well-being. American Psychologist, 55, 68-78.

Ryan, R. M., \& Sapp, A. (2005) Zum Einfluss testbasierter Reformen: High Stakes Testing (HST). Motivation und Leistung aus Sicht der Selbstbestimmungstheorie. [considering the impact of test-based reforms: A self-determination theory perspective on high stakes testing and student motivation and performance]. Unterrichtswissenschaft, 33 (2), 143-159. Available at https://core. ac.uk/download/pdf/33979992.pdf

Schreiber, J. B., Nora, A., Stage, F. K., Barlow, E. A., \& King, J. (2006). Reporting structural equation modelling and confirmatory factor analysis results: A review. The Journal of Educational Research, 99(6), 323-338.

Seligman, M. (2011). Flourish. New York: Free Press.

Simons-Morton, B., \& Chen, R. (2009). Peer and parent influences on school engagement among early adolescents. Youth \& Society, 41(1), 3-25.

Simons-Morton, B. G., \& Crump, A. D. (2003). Association of Parental Involvement and Social Competence with school adjustment and engagement among sixth graders. Journal of School Health, 73, 121-126. https://doi.org/10.1111/j.1746-1561.2003.tb03586.x.

Sinclair, M. F., Christenson, S. L., Lehr, C. A., \& Reschly-Anderson, A. (2003). Facilitating school engagement: Lessons learned from check \& connect longitudinal studies. The California School Psychologist, $8,29-41$.

Skinner, E. A., \& Belmont, M. J. (1993). Motivation in the classroom: Reciprocal effects of teacher behavior and student engagement across the school year. Journal of Educational Psychology, 85, $571-581$.

Slaten, C., Ferguson, J., Allen, K., Brodrick, D., \& Waters, L. (2016). School belonging: A review of the history, current trends, and future directions. The Educational and Developmental Psychologist, 33, 1-15. https://doi.org/10.1017/edp.2016.6.

Suldo, S. M., Gormley, M. J., DuPaul, G. J., \& Anderson-Butcher, D. (2014). The impact of school mental health on student and school- 
level academic outcomes: Current status of the research and FutureDirections. School Mental Health, 6(2), 84-99. https://doi. org/10.1007/s12310-013-9116-2.

UNESCO. (2018). UNESCO Institute for statistics. Country report. http://uis.unesco.org/country/KZ Accessed 24 May 2019.

Virtanen, T. E., Lerkkanen, M. K., Poikkeus, A. M., \& Kuorelahti, M. (2014). Student behavioral engagement as a mediator between teacher, family, and peer support and school truancy. Learning and Individual Differences, 36, 201-206.

Wang, M. T., \& Eccles, J. S. (2012). Social support matters: Longitudinal effects of social support on three dimensions of school engagement from middle to high school. Child Development, 83(3), 877-895.

Wang, M. T., \& Eccles, J. S. (2013). School context, achievement motivation, and academic engagement: A longitudinal study of school engagement using a multidimensional perspective. Learning and Instruction, 28, 12-23.

White, M. A., \& Murray, A. S. (Eds.). (2015). Evidence-based approaches in positive education: Implementing a strategic framework for well-being in schools. Dordrecht: Springer.

WHO. (2018). World Health Organization Global Health Observatory (GHO) data: Suicide rates per (100 000 population) https://www. who.int $/$ gho/mental_health/suicide_rates_crude/en/. Accessed 15 June 2019.

Winter, L., Rimini, C., Soltanbekova, A., \& Tynynayeva, M. (2014a). The culture and practice of assessment in Kazakhstan: The unified National Test: Past and present. In D. Bridges (Ed.), Educational reform and internationalisation: The case of school reform in Kazakhstan. Cambridge: Cambridge University Press.

Winter, L., Rimini, C., Soltanbekova, A., \& Tynynayeva, M. (2014b). The culture and practice of assessment in Kazakhstan: An alternative model and the future. In D. Bridges (Ed.), Educational reform and internationalisation: The case of school reform in Kazakhstan. Cambridge: Cambridge University Press.

Witherspoon, D., \& Ennett, S. (2011). Stability and change in rural youths' educational outcomes through the middle and high school years. Journal of Youth and Adolescence, 40(9), 1077-1090. https:// doi.org/10.1007/s10964-010-9614-6.

Woolley, M. E., \& Bowen, G. L. (2007). In the context of risk: Supportive adults and the school engagement of middle school students. Family Relations, 56(1), 92-104.

World Bank. (2002). Kazakhstan - governance and service delivery : A diagnostic report. Washington, DC: World Bank http://documents. worldbank.org/curated/en/563971468773755181/KazakhstanGovernance-and-service-delivery-a-diagnostic-report. Accessed 25 June 2019.

Zajonc, R. B. (1965). Social facilitation. Science, 149(whole no. 3681), 269-274. https://doi.org/10.1126/science.149.3681.269

Publisher's Note Springer Nature remains neutral with regard to jurisdictional claims in published maps and institutional affiliations. 